\title{
Poverty Alleviation and profitability in Microfinance delivery: Is there a Conflict or Complementarity?
}

\author{
Dr. Seeku A. K. Jaabi \\ First Deputy Governor, \\ Central Bank of The Gambia
}

\begin{abstract}
With a conspicuous absence of commercial banks in financing micro, small and medium enterprises, microfinance institutions (MFIs) emerged promising to finance growth and alleviate poverty by providing broad financial services to this vast market, thus expanding rural economic opportunities and reducing their vulnerabilities. MFIs have emerged to fill the crucial gap in banking this market niche in solving development problems of unemployment, poverty, income inequalities, enterprise growth, among others. Due to its socio-economic importance, enterprise finance has generated enormous enthusiasm among aid donors, governments and non-government organizations (NGOs) as an instrument for enhancing socio-economic development in a manner that is financially self-sustaining. The paper reports on a research which estimated the impact of microfinance institutions in The Gambia and selected MFIs in the developing world on poverty and other target variables, and attempted to relate such impact to the institutions' design features. The findings showed that impact of lending on the recipient household's income tend to increase, at a decreasing rate, as the recipient's income and asset position improved, a relationship which can easily be explained in terms of the greater preference of the poor for consumption loans, their greater vulnerability to asset sales forced by adverse income shocks and their limited range of investment opportunities. There are significant outliers to this general pattern with very poor people not adequately reached as the programme focus on productive poor. This relationship defines an "impact frontier" which serves as a tradeoff: lenders can either focus their lending on the poorest and accept a relatively low total impact on household income, or alternatively focus on the productive poor and achieve higher impact. The position and slope of the estimated impact curve vary however with the policy and design of the institutions. Hence for many lending institutions the trade-off can often be moved by appropriate innovations in institutional design, in particular modifications to savings, loan collection, skills training and incentive arrangements for customers and employees. Building strategic partnerships with development agencies have over the years achieved complementarity in mist developing economies.
\end{abstract}

Key Words: poverty alleviation, profitability, trade-off, microfinance JEL Codes:

\section{INTRODUCTION}

Several studies focused on microfinance as a poverty alleviation instrument (Yunus, 2002; Hulme \& Mosley 1996, 1998; Jaabi \& Chandran 2015; Remenyi, 1991; Yaron, 1991; Christen et al. 1994; Otero \& Rhyne, 1994; Robinson, 1996), with limited coverage on limitation of microfinance institutions reaching the poorest to address their deprivations. Providing affordable credit to the rural communities has long been a prime component of development strategy in developing countries. Governments and donors have sponsored and supported supply-led rural finance institutions to mitigate urban-biased macroeconomic policies. Microfinance Institutions was seen as the solution to development challenges in earlier days of its inception, however, increasingly recent evidence shows that it is less effective in reaching the poorest as much focus is directed to profitability. It therefore calls for social protection 
programmes of governments to reach this category considered below microfinance niche market.

The idea of attempting to reduce poverty in developing countries through the provision of financial services (particularly credit) by specialized financial institutions to microenterprises,' urban and rural, has in recent years generated enthusiasm bordering on hysteria (Rogaly, 1996). Politically, it appeals to the left as being redistributive and a direct approach to alleviating poverty, and to the right as facilitating the emergence of an independent, selfsustaining "penny capitalism." Financially, institutions such as the Grameen Bank of Bangladesh, the BKKs of Indonesia and BancoSol of Bolivia have often achieved higher loan recovery rates than those achieved by commercial banks in the same country in spite of lending to poor, uncollateralised individuals, making it appear that a reliable organisational technology for lending to the poor of developing countries now exists.

Elements in such a technology are the freedom to charge interest rates which cover costs, the provision of savings facilities and the adaptation of financial services to local demand through "mobile banking." Various institutional initiatives, including the World Bank-based Consultative Group to Assist the Poorest (CGAP), the Micro-Credit Summit held in Washington DC in February 1997 and 2005, the Dhaka-based Grameen Bank, India's ICICI and NABARD, Pakistan's SANASA, Rwanda's UNCDF financial inclusion programme, Asia's CASHPOR network and similar programmes in Brazil, have been taken to diffuse that technology, on the premise that so doing will make a large contribution to reducing the level of world poverty.

The implicit assumption behind such initiatives is that the existing technology reduces poverty; but this assumption, with the exception of studies of the Grameen Bank (Hossain, 1988, 1998; Khandker, Khalily \& Khan, 2007; Pitt \& Khandker, 1996) has rarely been tested. The major comparative studies of microfinance avoided calculations of poverty impact, often treating the fact that small loans are being made as in itself proof that the poor are being reached and the fact that loans are being repaid as proof that incomes have increased. As a consequence we remain rather ignorant about the poverty impact of existing microfinance schemes, and a fillioti about the possibilities for extending the "standard technology" outside the experimental target groups so far reached and into the banking sector in generally. This paper attempts on research designed to address this question. Having presented the introductory part, the scope and methodology adopted and review of literature are covered in section 2 and 3 respectively. General evidence of impact curve is presented in section 4 offering evidence supporting the idea that there is a systematic positive relationship between impact and household income, the position of which, however, appears to vary according to the design of the different institutional designs and schemes. BRAC's experience on ultra poor scheme (IGVGD) is also presented followed by the implications for policy and institutional design. The paper concludes with summary of findings on double bottom line strategies.

\section{SCOPE, METHOD AND AGGREGATE FINDINGS ON IMPACT}

In most developing countries, It is difficult to obtain reliable information on numbers of microfinance clients (borrowers and savers) as many alternative financial institutions do not report to monetary authorities. As a result, many authors collected information from hundreds of sources including databases maintained by institutions such as the World Bank, United States Agency for International Development, Consultative Group of Assisting the Poor (CGAP), World Council of Credit Unions, Microcredit Summit, and other networks. This information was updated and supplemented with data provided directly by many individual institutions and through third parties. 
Over the past decades, attempts have been made to measure the financial performance and income impact of large microfinance institutions ${ }^{1}$ across the developing world with a povertyreduction in intention aimed at very diverse segments of the income distribution and all using slightly different combinations of design features to achieve this objective. Financial performance is measured by means of two alternative indicators: the proportion of loans more than six months in arrears and the Subsidy Dependence Index,' which measures the extent to which interest rates would have to be raised to break even in an environment free of all subsidy. The two measures are highly correlated with the lowest indices of subsidy dependence having the lowest arrears rates and vice versa. Both of these measures may be taken as measures of financial sustainability/unsustainability; the higher they are, the harder it is for the lender to continue in business without subsidy. The "less financially sustainable" institutions are with arrears rates above $20 \%$ and the "more sustainable" institutions with arrears rates below $20 \%$, it appears that financial sustainability correlates not only with the charging of market interest rates and the availability of savings facilities (in line with the "Washington microfinance consensus" view) but also with frequency of loan collection and the existence or otherwise of material incentives to borrowers and staff of the lending agency to maximize the rate of repayment. It does not correlate with the tendency to lend to groups as both group and individual schemes were found in both the successful and the unsuccessful categories. All of these attributes are significantly greater for the "high sustainability" group than for the "low sustainability" group. Correlation does not imply causation, and it does not follow from the above that any of the design features mentioned can be proved to be a necessary condition for good financial performance.

This paper reports a surprisingly large number of savings and loan accounts USD500 million, in financial institutions that focus on a clientele that is generally below the level served by commercial banks. The large numbers being reported can lead to a facile impression that the task of reaching lower-income clients, especially poor clients, has been accomplished because so many people are already being served. No such conclusion is justified by the data reported in this paper. The institutions studied here serve many clients who are not poor or near-poor, probably including some people who could also use a commercial bank. Further, four-fifths of the accounts reported are savings accounts, and access-to-service problems may be greater for loans than for savings.

Most participants in the microfinance movement of recent decades see their goal as improving the availability and quality of financial services for poor and near-poor clients. Thus far, much of the movement's attention has been focused on a relatively new breed of specialized microfinance institutions (MFIs) that focus directly on this clientele. CGAP recently surveyed the global outreach of a broader set of institutions, all of which focus to some degree on extending financial services downward from the economic level of the traditional clients of commercial banks. Thus, these institutions have a "double bottom line": in addition to a financial objective, they also have a developmental or social objective. If their managers were asked which of the objectives is primary, most of them would say that the non-financial objective- extending outreach to people not normally served by banks-is the crucial one, and that solid financial performance is a means to that end rather than an end in itself. This paper will refer to these institutions as "alternative financial institutions (AFI)" in CGAP research countries in developing and transition economies. AFIs include state-owned agricultural, development, and postal banks; member-owned savings and loan institutions; other savings banks; low-capital local and/or rural banks; and specialized microfinance 
institutions and programs of varying types. Historically, almost all of these institutions were set up with an explicit objective of reaching clients who did not have access to services from commercial banks and finance companies

In assessing impact, attempts were made to calculate it by comparing the change in household income and other target variables in a random stratified sample of 100 borrowers with the change in that target variable in a control group of 50 non-borrowers selected so as to have similar initial income, asset holdings and access to infrastructure to the borrowing group.

\section{LITERATURE REVIEW}

The contemporary model of microfinance has its origin from Bangladesh in the early 1970s pioneered by the 2006 Nobel Peace Prize co-recipient Professor Muhammed Yunus. Microfinance is instrumental in supporting small informal micro-enterprises and providing avenues for self-employment to help resolve increasing poverty and by the 1990s; microfinance has become the international development communities' highest-profile and most funded poverty alleviation policy. Some development economists have alleged that the "new world of microfinance has the potential in finance as the green revolution in agriculture providing financial access on a considerable scale to micro, small and medium-sized enterprises" (Otero \& Rhyne, 1994:3). However, due to most microfinance organisations being NGOs and other small MFIs, they are constrained by funding and governance problems to reach out and meet financing requirements of SMEs adequately. The financing gap (as shown in Figure 1.1) remains high for SMEs to access sustainable external financial credit to support enterprise growth and development.

\section{Definition of Microfinance}

There is no rigid definition of what constitutes microfinance as it varies widely among institutions, countries and regions. We adopted the World Bank (1996:2) definition of microfinance as "consisting of organisations and agents that are engaged in relatively small financial transactions using specialised, character-based methodologies to serve the low-income households, micro, small and medium-sized enterprises, small farmers and others who often lack access to the formal banking system". It is the term generally used for the provision of financial services to a large number of micro, small and medium-sized enterprises in a cost effective and sustainable manner.

The concept has gained recognition as a tool for reducing poverty among large and diverse groups. Microfinance service providers may be formal financial intermediaries, semi-formal or informal institutions. Institutions engaged in these services ranges from NGOs, rotating savings and credit organisations (ROSCAs), credit unions, cooperatives, rural banks, commercial banks and other specialised financial institutions such as the development financial institutions (DFIs). The micro-economy is the primary market of microfinance institutions (MFIs) and includes such population segments as micro-enterprises, small farmers, landless and other low income people, among them women who are frequently and particularly disadvantaged in accessing formal external financial (Itsede, 2002).

Microfinancing as financial intermediation came into prominence globally to fill the credit gap in financing micro, small and medium enterprises after decades of formal banking sector failure to address their financing requirements. Lending methodology under group lending approach championed by Professor Muhammed Yunus (founder and former Managing Director of Grameen Bank) is mainly through loans made to individuals and enterprises with the group held jointly liable in cases of loan default. "In addition to repaying individual share of the loan, each member of the group must accept to pay the obligations of their defaulting members to 
avoid the entire group ineligible for future financing" (Aghion \& Gollier, 2000: 632; Yunus, 2006). Within the group lending system, peer support and pressure are crucial in ensuring full repayment. Chan (1997) cited that the system of social collateral form a concerted control mechanism making it possible for vulnerable, rural and urban borrowers have access to scarce resources who otherwise may go without it.

To address loan defaults, several studies found that group loans under joint liability reduces moral hazard problems. In analysing peer monitoring, Stiglitz (1990) argues that the obligation to pay loans for defaulting members under joint liability increase borrowers risks and costs. However, such obligation creates an incentive for intra-group monitoring as increased monitoring slows down the default probabilities and improves clients' welfare (Stiglitz 1990:80). Aghion \& Morduch (2000: 410) argue that the high repayment rates in Self-Help Groups (SHG) lending cannot be solely associated with the effect of joint liability but may be explained by other factors inherent in the lending technology such as training, client education, group participation in the credit markets and transparent public repayments ${ }^{2}$.

Despite the successes of Grameen Bank in Bangladesh, its lending model replication in more than 132 countries (Shakya \& Rankins, 2008) including India, Pakistan and Malaysia, among others; has not been encouraging with increasing rate of farmers' suicide in Andhra Pradesh, India (Chan et al. 2011; Mortana, 2011) due to excessive debt exposure. Some NGOs charge prohibitive interest rates and indulging in oppressive loan recovery practices, (Shylendra, 2006) while other unscrupulous NGO intermediaries in Benin Republic were employing irresponsible credit delivery and an aggressive recovery (IRIN, 2009) ${ }^{3}$. The case of Initial Public Offering (IPO) of Banco Compartamos ${ }^{4}$ is a case in point- the largest microfinance bank in Mexico revealed unethical behaviour of considerable profiteering by senior managers with no evidence of positive effect on poverty reduction among its poor clients (Bateman, Sinkovic \& Skare, 2012: 5)

However, lately microfinance once-globally praised mechanism for poverty alleviation has come under intense criticism. The high cost of fees and interest charges have driven most communities into huge indebtedness and the local district authorities in Andhra Pradesh blamed MFIs for increasing farmers' suicides that occurred as a result of non-payment of their debts. While some politically connected persons and cronies would consider public sector credit as political dividends, some governments in the past have written-off small farmers' loans to solicit votes in election years causing external financiers to experience considerable non-performing loans (NPLs). This is most notable in the Southern Indian state of Andhra Pradesh ${ }^{5}$, where loan repayment rates fell from almost 100 percent to a mere 20 percent $^{6}{ }^{6}$ see

\footnotetext{
2 Repayment of group loans is usually done in public at periodic weekly or monthly meetings so any defaults becomes public knowledge to all members of the groups. The threat of social stigma put further pressures on borrowers to repay loans.

3 Integrated Regional Information Network in Africa

${ }^{4}$ Compartamos charging $195 \%$ interest on microloan created much public outcry for enriching its senior managers and shareholders than reducing poverty of its clients and the general criticism of commercial microfinance

${ }^{5}$ Andhra Pradesh has a population of about 80 million people accounting for one third of India's microfinance loans, having a considerable effect on the lives of its people

${ }^{6}$ Nicaragua, Morocco, Bosnia and Bolivia have also faced similar negative effects of microfinance with politicians encouraging non-payment of government backed loans in exchange for grass-root political support. Similar problems also happened in some SSA countries notably The Gambia, Senegal, Uganda, Kenya, among others.
} 
Mortana, 2011)7 and also of Bosnia (Bateman et al, 2011), NGOs in Benin and Banco Compartamos in Mexico.

In the same vein, many researchers (Chan. 2011; Goetz et al. 1996; Hulme \& Mosley, 1996; Bateman \& Chang, 2012) have expressed concerns with the group lending approach adopted by Grameen Bank as credit may disempower borrowers leading to excessive debts and rising tensions at family level. It is reported that borrowers were forced to eat less to meet loan payments, experience indignity of losing their collateralised assets in default cases, loss of confidence and sleep less worrying about their next installment payments (Goetz \& Gupta, 1996). Copestake (2002:752) also found out that some micro and small entrepreneurs become worst-off after taking microfinance loans than before (Hulme \& Mosley, 1996, 1998:787). Group lending continues to be criticised due to its high cost of implementation, replication, difficulties in reaching large number of borrowers and its programs are often unsustainable due to continuous dependence on subsidies (Bhatt \& Tang, 2001; Robinson, 2001; Ledgerwood, 2002; Christen, 2008).

Advocates of financial system approach, such as Robinson (2001); Rhyne \& White (2000); Ledgerwood (2002) and Hulme \& Mosley (1996, 1998:783-790) have been critical of Grameen Bank's lending technologies. They argued that NGO subsidy dependent approach requires a huge amount of continuing subsidies to sustain it and has not proof to be a global affordable model. Much reliance on donor and government funds has not been sustainable as growth prospects become limited and wind-up if such funds dry out. Accordingly, even if the long-term continuance of these subsidies is assured, these assumptions do not match very well with the real world (Robinson, 2001; Rhyne et al. 2000). The probable irreversible trend of banks in financing small and medium enterprises may be due to significant unmet demand of this sector (Robinson, 2001; Ledgerwood, 2000 and Khandler, 1998) and the fact that it has been proven that this massive unmet demand on a global scale can be met profitably through financial system approach able to cover intermediation costs and remain self-sufficient.

Despite its attempts to fill the credit gap, microfinance is not a magic wand (Hulme \& Mosley, 1996, 1998; Robinson, 2001; Rhyne \&White, 2000; Montana, 2011), like all financial institutions it is wrought with the ups and downs of the market. Lending system could be dangerous especially when enterprises are allowed to borrow irresponsibly, seen as the buildup of both the Southeast Asian financial crisis of 1997/8 and global financial crisis of 2008 (see Corsetti et al. 1999; King, 2001; Rao, 1998 and Crafts, 1999 on Asian crisis and Reinhart \& Rogoff, 2008, 2009; Lall, Cardarelli \& Elekdag, 2008; Krugman, 1990 and Hong, lee \& Tang, 2010 on global financial crisis). Several studies including Mortana (2011); Robinson (2001); Rhyne \& White (2000) and Rhyne (2011) have argued that microfinance does work with responsible lending and provision of broader range of financial products and services, including not just credit but also savings, remittances, insurance, leasing and factoring. It is not a magic bullet to address poverty immediately, nor is it intrinsically harmful.

\footnotetext{
7 Mortana, (2011) Microfinance Isn't a Magic Bullet, available on http//:www.globalenvision.org/topics/governance
} 
Table 1: Alternative Financial Institutions Per Capita by Region

\begin{tabular}{lrrc}
\hline Region & Population & Total Accounts & Accounts percent \\
\hline Africa Sub-region-AFR & 666 & $27,000,000$ & 4 \\
East Asia \& Pacific, Including China & 1,8666 & $319,000,000$ & 17 \\
China Only & $1,280,975,000$ & $157,000,000$ & 12 \\
Europe \& Central Asia - ECA & $385,369,332$ & $18,000,000$ & 5 \\
Latin America \& Caribbean - LAC & $515,988,980$ & $14,000,000$ & 3 \\
Middle East \& North Africa - MENA & $377,797,840$ & $49,000,000$ & 13 \\
South Asia (including India) & $1,372,806,710$ & $238,000,000$ & 17 \\
India Only & $1,048,279,000$ & $188,000,000$ & 18 \\
\hline TOTAL & $\mathbf{5 , 1 8 3 , 7 3 1 , 6 9 2}$ & $\mathbf{6 6 5 , 0 0 0 , 0 0 0}$ & $\mathbf{1 3}$ \\
\hline
\end{tabular}

AFIs at a global level show varying accounts and per capita as shown above in Table 1 East Asia and Pacific (including China) showing the highest accounts followed by South Asia (including India), then India only, China only among others.

Figure 1: Relationship -Average Borrower Income to Average Increase in Household Income

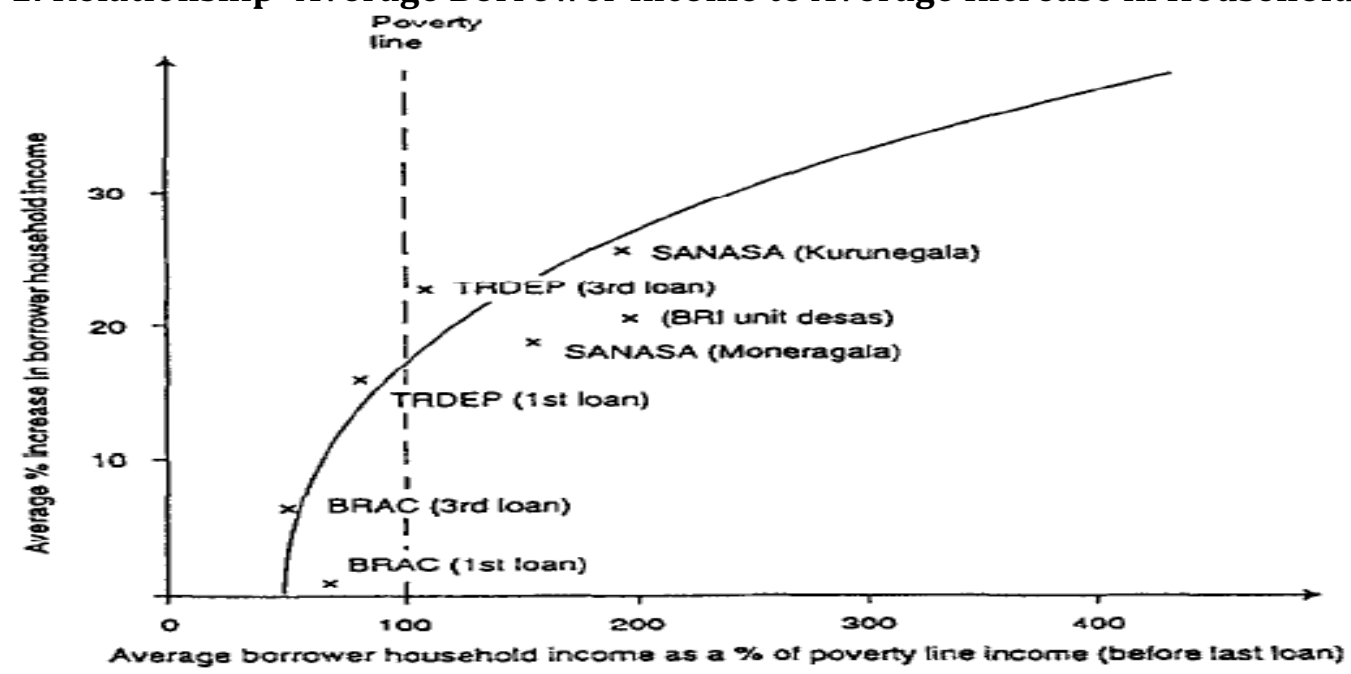

Source: Adapted from Hulme and Mosley (1998: pp786)

EVIDENCE OF THE IMPACT CURVE

Figure 1 and Figure 2 represent the measured relationship between borrower household income and loan impact on household income for two different populations. Figure 1 shows the relationship between average income level (measured as a percentage of the national poverty line) and average loan impact across institutions. In Figure 2 the relationship between income level and loan impact across borrowers within institutions is shown. In both cases the estimated relationship is a curve (referred to as 'impact curve') sloping upwards at a decreasing rate. it is positive in income but negative in the square of income, as depicted by the regression equations in Table 1 . The regression coefficients on these terms are significant, except in the case of Malawi Mudzi Fund. In other words, higher-income households experience on average higher program impact than households below the poverty line, eg. BRAC first and third loans, TRDEP first loan. For households a long way below the poverty line average loan impact is negative, although there are outliers from this trend, some of them depicted in Figure 1 and Figure 2.

In addition, the slope coefficients for the different institutions differ: generally, as a consequence, the curves for the "more financially sustainable" institutions (Bolivia BancoSol, Indonesia BRI and BKK/KURK) lie above the curves for the "less financially sustainable" institutions (Kenya K-REP, Malawi SACA and Malawi Mudzi Fund), suggesting a higher average 
loan impact in the financially sustainable institutions. This is true for social promotion financial services able to charge sustainable interest rates relative to social protection subsidised interest rates associated with low impact.

Again, this is consistent with the picture emerging from Figure 1 and 2. It is believed that the upward slope of the impact curve reflects a tendency for the willingness to take risks and to invest in new technology to increase with income. The poor are probably more risk-averse. Very poor borrowers, given the choice, tend to take out small, subsistence protecting loans; these are seldom invested in new technology, fixed capital or even the hiring of labour but rather in working capital or in a majority of cases, in protecting consumption standards. As a consequence, loans to the very poor are not normally able to produce dramatic impact in borrower's income and quality life. At these lower levels of income, there is also a greater risk that improvident borrowers may be forced by their greater exposure to debt into selling assets which will permanently lower their income possibilities.

Figure 2: Loan impact in relation to borrower income

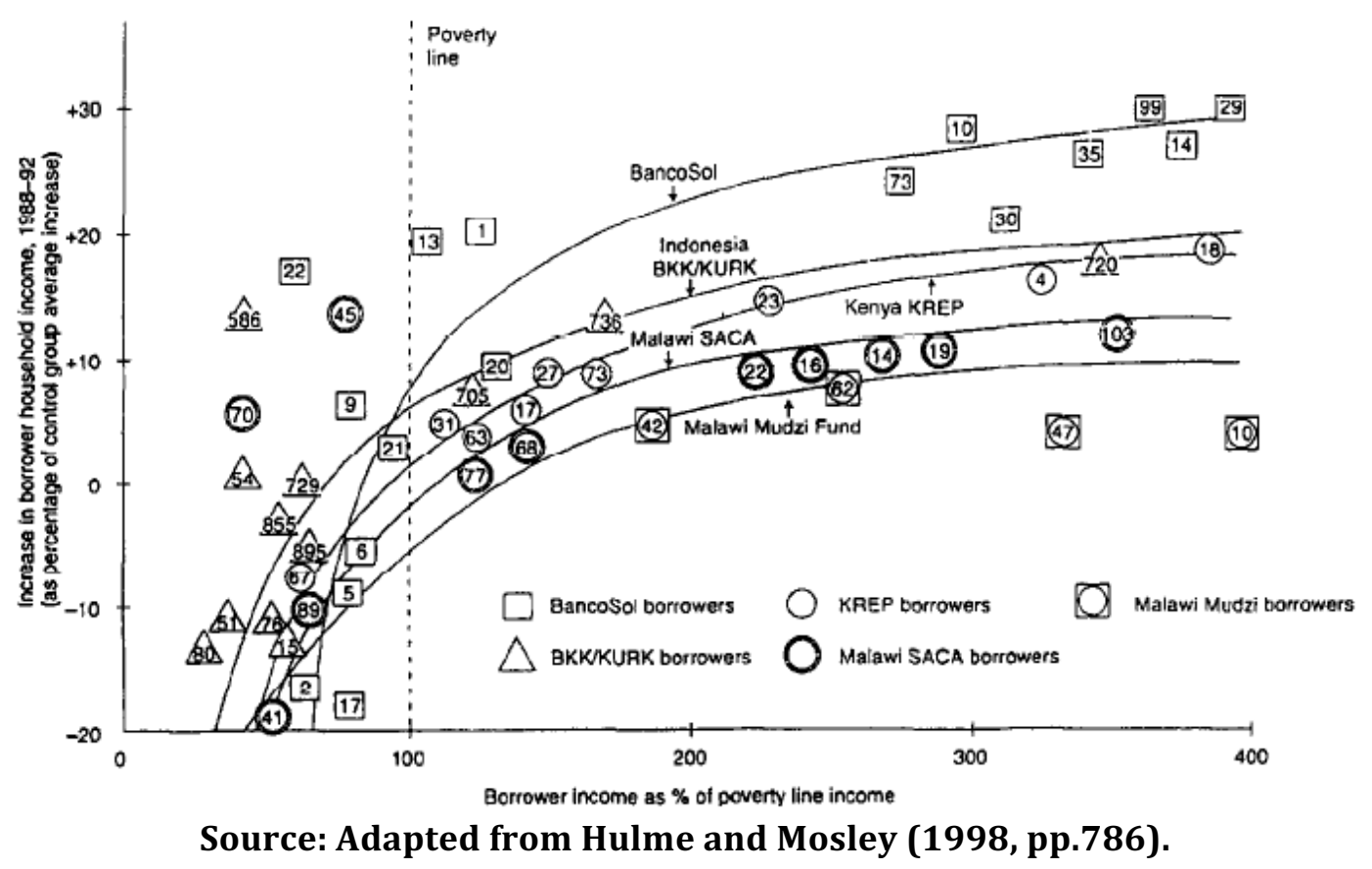

Figure 2 provides more insight into the relationship between financial sustainability and poverty reduction. Three conclusions can be drawn including the following:

i. Program impact increases at a decreasing rate with client income. In other words, borrower households above or on the poverty line experience a higher average income impact than households below the poverty line, in comparison with income changes encountered by a control group.

ii. For the very poor, loan impacts are on average, small or negative in comparison to the control group, although there are some important exceptions to this rule which deserves further research.

iii. The impact curves for Group A institutions lie consistently above the curves for Group B institutions, suggesting that it may be possible to increase average program impact by adopting best practice features that increase financial sustainability.

The findings maintain that higher income borrowers experience a greater income impact because clients above the poverty line are willing to take risks and invest in technology for promotional activities more likely to increase income flows. On the other hand, very poor 
borrowers, tend to take out small subsistence, social protection loans and seldom invest in new technology, fixed capital and human resource. These loans do not tend to produce dramatic changes in borrower income instead may worsened the borrower status by plunging into deeper debt beyond the capacity to repay loans.

Table 2. Microfinance institutions: Determinants of impact

\begin{tabular}{|c|c|c|c|c|c|c|c|}
\hline \multirow{3}{*}{$\begin{array}{l}\text { Institution(size } \\
\text { of borrower } \\
\text { sample in } \\
\text { brackets) }\end{array}$} & \multirow{2}{*}{\multicolumn{2}{|c|}{$\begin{array}{l}\text { Financial performance } \\
\text { data for the institution }\end{array}$}} & \multicolumn{5}{|c|}{ Institution(size of borrower sample in brackets) } \\
\hline & & & \multirow{2}{*}{$\begin{array}{l}\text { (a)Mean } \\
\text { loan impact } \\
\text { per } \\
\text { borrower } 8\end{array}$} & \multicolumn{3}{|c|}{ (b) Regression coefficients on impact of: } & \multirow[t]{2}{*}{$\mathbf{R}^{2}$} \\
\hline & SDI $^{9}$ & $\begin{array}{l}\text { Arrears } \\
\text { rate }^{10}\end{array}$ & & Constant & $\begin{array}{l}\text { Borrower } \\
\text { income } 11\end{array}$ & $\begin{array}{l}\text { Borrower } \\
\text { income } \\
\text { squared }\end{array}$ & \\
\hline BancoSol (100) & 135 & 23 & 270 & $\begin{array}{l}-15.12^{* * 12} \\
(2.80)\end{array}$ & $\begin{array}{l}0.20^{* *} \\
(2.80)\end{array}$ & $\begin{array}{l}-0.00027 \\
(1.63)\end{array}$ & 0.44 \\
\hline BRI (280) & 32 & 11 & 216 & $\begin{array}{l}-30.74^{* *} \\
(5.47)\end{array}$ & $\begin{array}{l}0.55^{* *} \\
(5.42)\end{array}$ & $\begin{array}{l}-0.0018^{* *} \\
(4.57)\end{array}$ & 0.52 \\
\hline KREP (145) & 217 & 7 & 133 & $\begin{array}{l}-37.6^{* *} \\
(5.01)\end{array}$ & $\begin{array}{l}0.58^{* *} \\
(4.68)\end{array}$ & $\begin{array}{l}-0.0019 * * \\
(4.17)\end{array}$ & 0.38 \\
\hline SACA (160) & 398 & 13 & 175 & $\begin{array}{l}-39.5^{* *} \\
(3.46)\end{array}$ & $\begin{array}{l}0.53^{* *} \\
(4.01)\end{array}$ & $\begin{array}{l}-0.0015^{* *} \\
(2.79)\end{array}$ & 0.67 \\
\hline $\begin{array}{l}\text { Mudzi Fund } \\
\text { (150) }\end{array}$ & 1600 & 41 & 125 & $\begin{array}{l}-69.8^{* *} \\
(2.11)\end{array}$ & $\begin{array}{l}1.29^{* *} \\
(1.46)\end{array}$ & $\begin{array}{l}-0.006 \\
(0.80)\end{array}$ & 0.21 \\
\hline $\begin{array}{l}\text { Uganda UFT } \\
(150)\end{array}$ & 160 & 12 & 180 & $\begin{array}{l}-23.21^{* *} \\
(2.6)\end{array}$ & $\begin{array}{l}0.23^{* *} \\
(2.4)\end{array}$ & $\begin{array}{l}-0.0011^{* *} \\
(2.72)\end{array}$ & 0.48 \\
\hline CERUDEB (180) & 252 & 21 & 136 & $\begin{array}{l}-24.46^{* *} \\
(3.11)\end{array}$ & $\begin{array}{l}0.35^{* *} \\
(4.31)\end{array}$ & $\begin{array}{l}-0.005^{* *} \\
(2.03)\end{array}$ & 0.56 \\
\hline $\begin{array}{l}\text { Faulu Kenya } \\
(220)\end{array}$ & 116 & 18 & 145 & $\begin{array}{l}-17.64^{* *} \\
(5.2)\end{array}$ & $\begin{array}{l}1.12^{* *} \\
(1.34)\end{array}$ & $\begin{array}{l}-0.008^{* *} \\
(1.83)\end{array}$ & 0.48 \\
\hline
\end{tabular}

Source: Filed survey data.

Malawi Small Agricultural Credit Association, Kenya rural enterprise project,

By contrast, loans to higher income activities (citing the terminology of Dreze \& Sen, 1990) such as the purchase of fixed capital and the hiring of labour from outside the borrower family. In addition, higher income households can commonly access larger loans because of their greater savings capacity and their ability to offer collateral and this widens the choice of investment opportunities to include "lumpy" investments. Likewise, there are good reasons why more financially sustainable financial institutions may have higher impact as in BRI, BKK and Bancosol. These financial institutions tend to charge relatively high rates of interest, which act as a screen to deter borrowers whose projects have relatively low rates of return. They tend to operate savings schemes, which provide a limited degree of insurance to protect repayments if projects fail to yield expected rates of return and serves to screen out prospective borrowers who lack financial discipline. They also tend to collect loan instalments frequently closer to the borrower's premises, which tends to deter borrowers with projects yielding low returns.

The impact curve represents only an underlying relationship for each institution, and a substantial part of the variation in loan use between borrowers cannot be explained by

\footnotetext{
8 Change in income of borrower household as percentage of change in income of a "control group" of non-borrowers living in same area and having similar income, assets, and access to infrastructure as the sampled borrower group

${ }^{9}$ Subsidy Dependence Index, see Yaron (1991) is a measure of the percentage by which the lending institution's interest rate would have to be raised to cover its costs.

10 Percentage of borrowers more than six months in arrears on final day of year specified.

11 'Initial income (as measured before loan intervention).

12 Significant at the $5 \%$ level; ${ }^{* *}$ significant at the $1 \%$ level
} 
income; in other words there are significant outliers to all the impact curves represented on Figure 2. Particularly interesting among these outliers are those lying above the left-hand end of the impact curves, i.e. very poor households who, against the general pattern, achieved substantial increases in income from their loans. A preliminary analysis of these outliers suggests that they typically fell into the rather specialized category of capital investments entailing a low increase in risk (eg. irrigation scheme in Malawi, high yielding seeds in rain sufficient areas in Indonesia and the handicraft making equipment in Bolivia). The existence of such investment opportunities is dependent on personal circumstances and on the specific economic environment in which an institution is operating.

Table 3: Overview of Microfinance Institutions - Profitability and poverty reduction

\begin{tabular}{|c|c|c|c|c|c|c|c|c|c|c|}
\hline & $\begin{array}{l}\text { Number of } \\
\text { borrowers }\end{array}$ & $\begin{array}{l}\text { Real } \\
\text { interest } \\
\text { rates }\end{array}$ & $\begin{array}{l}\text { Subsidy } \\
\text { dependence } \\
\text { Index }\end{array}$ & $\begin{array}{l}6 \mathrm{mth} \\
\text { arrears } \\
\text { rate }\end{array}$ & $\begin{array}{l}\text { Voluntary } \\
\text { savings }\end{array}$ & $\begin{array}{l}\text { Frequency } \\
\text { of loan } \\
\text { collection }\end{array}$ & $\begin{array}{l}\text { Incentive } \\
\text { to repay }\end{array}$ & $\begin{array}{l}\text { Borrowers } \\
\text { below } \\
\text { poverty } \\
\text { line (\%) }\end{array}$ & $\begin{array}{l}\text { Av. Incre } \\
\text { borrowe } \\
\text { as } \% \text { of } \\
\text { group } \\
\text { Whole } \\
\text { sample }\end{array}$ & $\begin{array}{l}\text { Ise in } \\
\text { income } \\
\text { ntrol } \\
\text { People } \\
\text { below } \\
\text { poverty } \\
\text { line }\end{array}$ \\
\hline \multicolumn{11}{|l|}{ Group A } \\
\hline Bancosol & 51000 & 45 & 135 & 0.6 & $\mathrm{Y}$ & M & 1 & 29 & 270 & 101 \\
\hline $\begin{array}{l}\text { BRI Unit } \\
\text { Desa }\end{array}$ & 1800,000 & 6 & 9 & 3.0 & $\mathrm{Y}$ & W & 2 & 7 & 544 & 112 \\
\hline BKK & 499,000 & 60 & 32 & 2.1 & $\mathrm{Y}$ & W & 2 & 38 & 216 & 110 \\
\hline BURK & 158,000 & 60 & 35 & 13.7 & $\mathrm{Y}$ & W & 2 & 29 & & \\
\hline $\begin{array}{l}\text { Grameen } \\
\text { Bank }\end{array}$ & 1050,000 & 15 & 142 & 4.5 & $\mathrm{~N}$ & W & 1 & $\begin{array}{l}\text { Vast } \\
\text { majority }\end{array}$ & 131 & 126 \\
\hline BRAC & 598,000 & 11 & 199 & 3.0 & $\mathrm{~N}$ & W & 1 & $\begin{array}{l}\text { Vast } \\
\text { majority }\end{array}$ & 143 & 134 \\
\hline TRDEP & 25,000 & & 199 & 0.0 & $\mathrm{~N}$ & W & 1 & $\begin{array}{l}\text { Vast } \\
\text { majority }\end{array}$ & 138 & 133 \\
\hline PTCC & 702,000 & 11 & 226 & 4.0 & $\mathrm{Y}$ & M & 1 & 52 & 157 & 123 \\
\hline KREP & 2400 & 9 & 217 & 8.9 & $\mathrm{Y}$ & W & 1 & & 133 & 103 \\
\hline $\begin{array}{l}\text { Average } \\
\text { Group A }\end{array}$ & 542,822 & 27.1 & 132.7 & 4.4 & & & & & 2165 & 117.8 \\
\hline \multicolumn{11}{|l|}{ Group B } \\
\hline $\begin{array}{l}\text { India } \\
\text { RRB }\end{array}$ & $12,000,000$ & 3 & 133 & 42.0 & $\mathrm{Y}$ & $\mathrm{A}$ & 0 & 44 & 202 & 133 \\
\hline $\begin{array}{l}\text { Kenya } \\
\text { KIE-ISP }\end{array}$ & 1700 & -1 & 267 & 20.2 & $\mathrm{~N}$ & M & 0 & 0 & 125 & \\
\hline $\begin{array}{l}\text { Malawi } \\
\text { Mudzi } \\
\text { Fund }\end{array}$ & 223 & 8 & 1884 & 43.4 & $\mathrm{~N}$ & W & 1 & $\begin{array}{l}\text { Vast } \\
\text { majority }\end{array}$ & 117 & 101 \\
\hline $\begin{array}{l}\text { Malawi } \\
\text { SACA }\end{array}$ & 400,062 & 7 & 398 & 27.8 & $\mathrm{~N}$ & A & 0 & 9 & 175 & 103 \\
\hline $\begin{array}{l}\text { Average } \\
\text { Group B }\end{array}$ & $3,100,496$ & 4.3 & 670.5 & 33.4 & & & & & 154.5 & 112.3 \\
\hline
\end{tabular}

Repayment intervals, $M=$ Monthly, $W=$ Weekly, A- Annually, Incentives to repay - 0- none, 1= larger repeated loans only available if repayment performance is satisfactory $2=$ as in 1 , plus staff pay and borrower interest rates related to repayment performance

Can MFIs achieve financial sustainability and reach the poorest of the poor? What are the trade-offs in pursuing these two goals simultaneously? These are among the key questions being addressed in this paper. The different MFIs as shown in Table 3 above are all poverty reduction in intention and all using different combinations of design features which are reviewed to assess the influence of such institutional designs, management and policy environments on financial sustainability and on various measures of impact, including poverty. Table 3 shows both financial performance and poverty impact results of MFIs studied above. The institutions with high financial sustainability (Group A) have lower arrears rates and subsidy dependence indices (SDI) than those with lower sustainability (Group B). In addition, financial sustainability appears to correlate with recognised 'best practice' design features such as high interest rates, the availability of voluntary savings facilities, the frequency of loan 
collection and the existence of material incentives to borrowers and including staff to maximize repayment.

The relationship between financial sustainability and poverty reduction becomes more ambiguous. Group A institutions produce more income impact than Group B institutions. However, the proportion of clients under the poverty line ranges dramatically from $7 \%$ at BRI (Group A) and Malawi SACA 9\% (Group B) to the 'vast majority' in the Bangladesh organisations (Group A) institutions who do not target poorer clients than Group B institutions.

\section{BRAC'S EXPERIENCE WITH THE ULTRA POOR PROGRAMME}

Bangladesh Rural Advancement Committee (BRAC) is an NGO financial institution turned commercial bank in Bangladesh attempting to bank the population of Bangladesh regardless of income levels.

\section{Figure 3: BRAC Ultra Poor Programme Design}
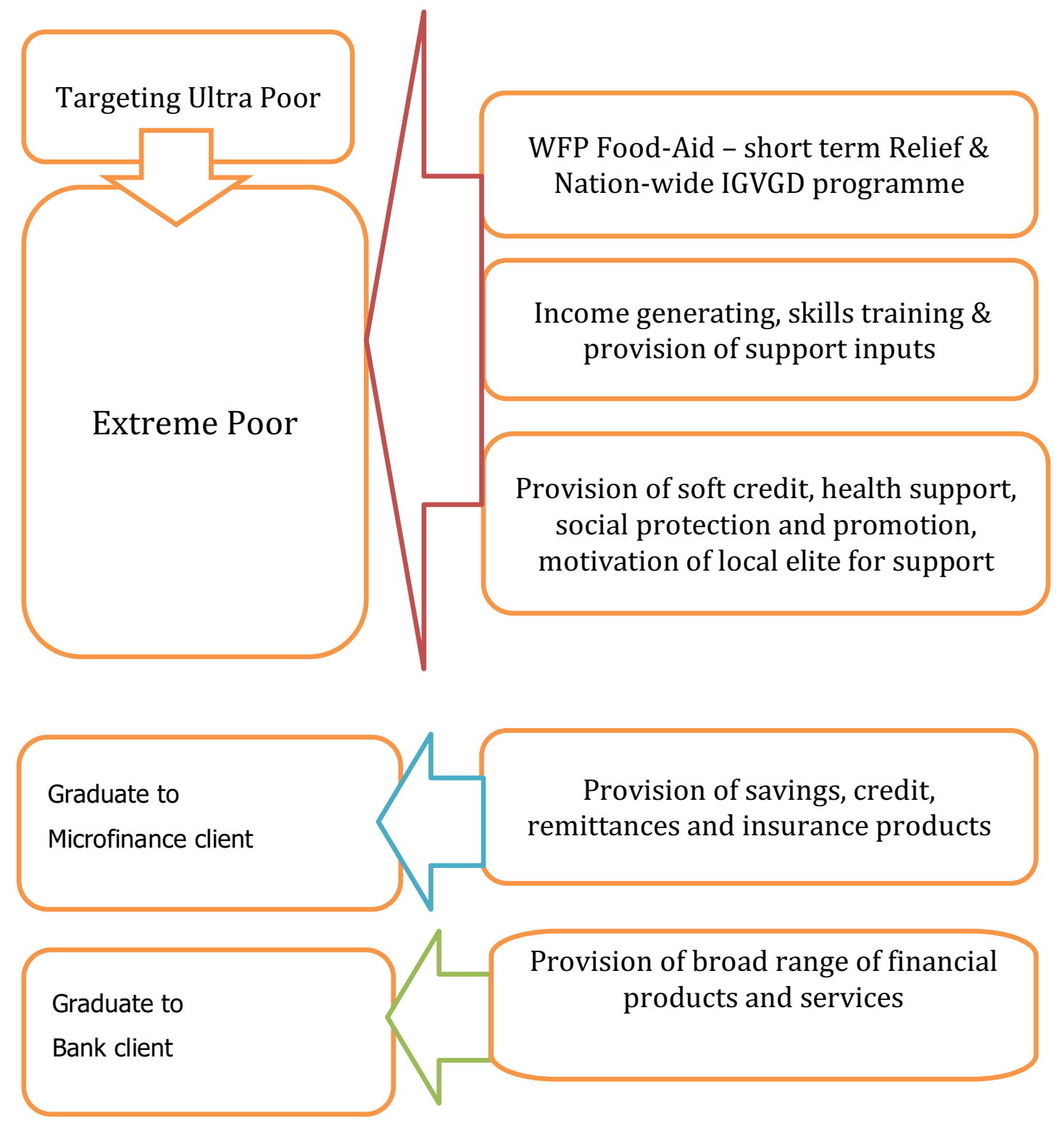

Source: Author review 
It was realised that microfinance alone is not as suitable an entry point for the extreme poor as it is for the productive poor. Again mere food aid provides short term relief without building any foundations for sustainable change will remain challenging. This was the driving motivation for BRAC in approaching the World Food Programme (WFP) in 1985 to pilot a 'laddered strategic linkage' approach that would transform WFP's feeding programme for the extreme poor to feed into the nation-wide Income Generation for Vulnerable Group Development (IGVGD) Programme

With over a quarter of Bangladesh's people live in extreme poverty ${ }^{13}$, not being able to meet even the barest of the basic needs, strategizing measures to bring on board that majority into the financial platform is indeed a challenging one. They spend most of their meagre, unreliable earnings on food and yet fail to fulfil the minimum calorie intake needed to stave off malnutrition. They are consequently in frequent poor health causing further drain on their meagre resources due to loss of income and health expenses (Hossain \& Matin, 2004). More often than not, the extreme poor are invisible even in their own communities, living on other peoples' land, having no one to speak up for them or assist them in ensuring their rights. Extreme poverty also has a clear gendered face - they are mostly women who are dispossessed widows, and abandoned.

The extreme poor are thus caught in a vicious trap and the story of denial and injustices tend to continue over generations for a large majority of them. Thus, a vast majority of the extreme poor in Bangladesh are chronically deprived. The constraints they face in escaping extreme poverty are interlocked in ways that are different from those who are moderately poor. This challenges development agencies to rethink over innovative development strategies and interventions for the extreme poor, and come up with better alternatives that work for them. This is the challenge that drove BRAC to initiate an experimental programme since 2002 called, "Challenging the Frontiers of Poverty Reduction: Targeting the Ultra Poor' programme".

The idea to address the constraints that they face in asset building, in improving their health, in educating their children, in getting their voices heard, in a comprehensive manner so that they too can aspire, plan, and find their way out of poverty. The extreme poor have not only been bypassed by most development programmes, but also by mainstream development research. We need to know much more about their lives, struggles, and lived experiences. We need to understand better why such extreme poverty persists for so many of them for so long, often over generations. Without such knowledge, we cannot stand by their side and help in their struggles to overcome their state.

Focusing policy attention towards the extreme poor is important because their existing opportunities can be severely constrained due to mismatches between the structure of opportunities available and the complex structure of constraints they face. For instance, it is by now accepted that mainstream development approaches, especially microfinance, largely bypass the extreme poor. However, evidence also suggests that microfinance has provided an important opportunity for moderate poor households to overcome poverty and reduce vulnerability (Khandker 1998; Morduch 1998). Market-mediated opportunities may also bypass the extreme poor because they lack the human and social capital needed to participate and benefit from such opportunities, and/or because they live in areas or belong to ethnicities

13 20-34 per cent of the population of Bangladesh lives in extreme poverty. This is a significant number of people requiring immediate and special attention, if Bangladesh is to fulfil its commitment towards attaining the Millennium Development Goals (MDG) which underpins its Poverty Reduction Strategy Paper 
that are bypassed or excluded due to their lack of voice and representation in policy-making processes.

On all the expected dimensions - land ownership, food security, health and nutrition, educational status - the ultra poor fare substantially worse than the rural national average. An important challenge to improving the livelihoods of the ultra poor is their low initial stocks of social capital. Dimensions of poverty in Bangladesh generally include 'poverty in people', but in this respect the ultra poor are poorer than the average, while 8 per cent of rural households are headed by women, fully 40 per cent of ultra poor households as targeted by BRAC are women-headed households. A defining characteristic of the ultra poor is their inability to even achieve 'adverse incorporation' into relations of dependency, relations which may at least ensure security, although at a cost (Wood 2000).

BRAC started a new programme for the extreme poor known as "Challenging the Frontiers of poverty Reduction/Targeting the Ultra Poor (CFPR/TUP)" programme in January 2002. A historical perspective of BRAC's development programmes helps to explain its current engagement with the extreme poor. Since 1972, BRAC was concerned with developing programmes for the extreme poor. Its foundational work began with addressing the immediate needs of the refugees who returned to Bangladesh after the country's freedom struggle of 1971. Gradually, BRAC moved beyond relief work to building sustainable livelihoods of the poor with a particular focus on women through an incrementally wide range of development programmes in the areas of microfinance, sector programmes, education, health, nutrition, and social development. The concern with the extreme poor in BRAC's microfinance programme is implemented by targeting households through its official definition of eligibility. In addition to the standard 'less than 50 decimals of owned cultivable land' criterion used by most microfinance institutions, BRAC also uses 'household selling at least 100 days of manual labour' as an official expression of its commitment to include the very poor.

However, very soon BRAC came to realise that microfinance alone is not as suitable an entry point and intervention for the extreme poor as it is for the productive poor. Severe malnutrition and hunger typically characterises the situation of the extreme poor, and without immediate attention to addressing these constraints, microfinance would certainly fail them. Yet, mere food aid provides short term relief without building any foundations for sustainable change. This was the driving motivation for BRAC in approaching the World Food Programme (WFP) in 1985 to pilot a 'laddered strategic linkage' approach that would transform WFP's feeding programme for the extreme poor then called the Vulnerable Group Feeding Programme (VGF) into the nation-wide Income Generation for Vulnerable Group Development (IGVGD) Programme. The basic idea was to leverage the two-year food aid period supported by WFP through appropriate income generation and social development training, develop a regular savings habit, provide small amounts of microcredit and offer the opportunity of eventual inclusion into BRAC's mainstream development programmes through membership of its village organisations. What started off as a BRAC pilot to bring the extreme poor within the fold of its microfinance and other development programmes is today a nation-wide programme working with over 4.5 million extreme poor and vulnerable women in 268 councils (Hashemi 2001; Matin \& Hulme 2003; Matin \&Yasmin 2004). Almost 70 per cent of the women who join BRAC's VGF programme through the IGVGD programme manage to continue as active microfinance members. However, those who do not continue as stable microfinance members are also among the poorest and the most vulnerable (Webb et al. 2006). Moreover, many extreme poor women also lack the social networks necessary to obtain Vulnerable Group Development membership, which is decided by local government representatives (Matin \& Hulme, 2003). 
The key factor underlying BRAC's success in engaging village elite support appears to be related to the prestige involved with connections to BRAC. As the largest NGO in the country, BRAC has an image and status among rural people unrivalled by other NGOs and possibly by other private sector organisations. In addition to its microfinance programmes, which reach more than 6.5 million borrowers, BRAC has schools, universities, women rights advocacy centers, clinics and related social services, as well as marketing vital producer and consumer goods such as seeds and fresh milk. The fact that BRAC is a large, well-networked, powerful organisation is clear to rural people, including the village elite. The BRAC intervention thus connects village elites to a large-scale development programme which has to date brought tangible benefits to at least some of the community. BRAC is viewed by village elites as an investment with potential future pay-offs. There is evidently some prestige to be derived from BRAC's IGVGD programme, among others is to promote the Bangladesh's lots of extreme poor population into the financial landscape to achieve the double bottom line of poverty alleviation and profitability incorporating wide range of financial services.

\section{The Graduation Model}

People at the very bottom of the economic ladder are often excluded, or they exclude themselves from microfinance. Their income is usually too low and unreliable to permit repayment of loans or investment in anything but basic food consumption. In some countries, the very poor are served by safety net programs, which usually take the form of cash transfers, food aid, or guaranteed employment schemes. In 2006, CGAP and the Ford Foundation have been exploring how a "graduation model" can create pathways out of extreme poverty, adapting a methodology developed by BRAC in Bangladesh.

The graduation model targets the "ultra poor"14 using safety nets to help these very poor people survive but it does not allow them to build up assets. The graduation program combines support for immediate needs with longer term investments in training, financial services, and business development so that within two years ultra poor people are equipped to help grow out of extreme poverty.

Table 4: Graduation Model of Ultra Poor

\begin{tabular}{lclc}
\hline Market & Regular Monitoring & Sustainable Livelihood \\
Analysi & $\bullet$ & Health Support & Access to Credit \\
$\mathbf{s}$ & $\bullet$ & Social Massaging & \\
\hline
\end{tabular}

Poverty Line

Extreme Poverty

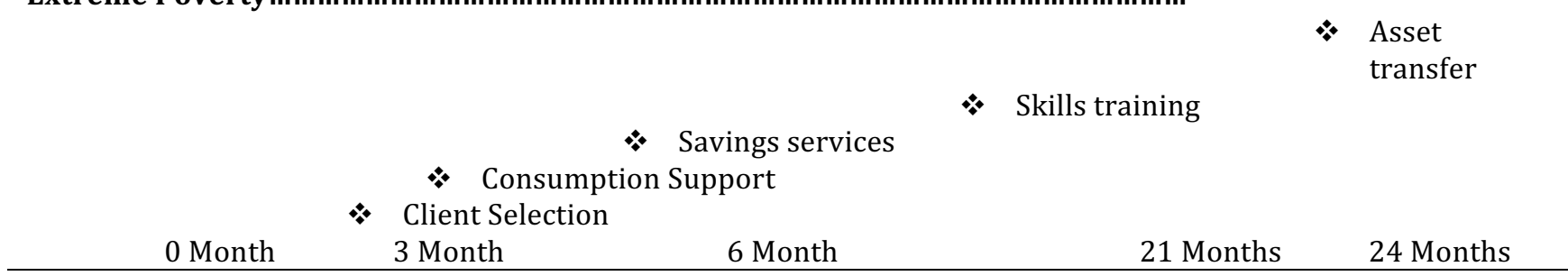
Source: CGAP (2009)

The term "graduation" refers to participants moving out of safety net programs and "graduating" into income-earning activities that let them sustain themselves without external subsidies. The graduation approach was originally developed by BRAC in Bangladesh specially targeting the Ultra Poor in the program with over 70 percent of participants currently food

\footnotetext{
${ }^{14}$ people who have no assets and are chronically food insecure
} 
secure and managing sustainable economic activities. Since 2006, CGAP and Ford Foundation have adapted BRAC's experience replicating into many countries with nine graduation pilots are underway, in Ethiopia, Haiti, Honduras, India, Pakistan, Peru, Rwanda and Yemen, involving diverse institutional forms, economic contexts, and cultures. The pilots are implemented through partnerships among financial service providers, non-governmental organizations (NGOs), and government safety net programs. Several of the pilots are measuring the program's effect on people's lives through rigorous randomized impact evaluations and qualitative research.

Careful client selection is critical to ensure only the poorest households are being selected. Community-level participatory wealth rankings and simple household surveys identify the poorest. In addition, household visits by senior managers have proved necessary to avoid participation by better-off people in the program. Since the model is based on household-level economic activities, only people who are physically or mentally able to manage enterprises can be included. After participants are selected into the program, they start receiving consumption support in the form of a small cash stipend or goods in kind. This support gives them "breathing space" by stabilizing their consumption. It can be offered through a pre-existing safety net program.

Discussing the amount and duration of the support with participants builds trust and helps them plan ahead when the support stops. Once people's food consumption stabilizes, they are encouraged to start saving, usually in an individual account at a microfinance institution (MFI). In addition to building assets, regular savings instills financial discipline and familiarizes potential participants with the MFI. Most pilot sites have felt the need to teach participants about cash and financial management.

Participants receive skills training in building assets and running a business, such training is essential in managing successful small businesses. The training also provides information on where to go for assistance and services.

A few months after the program starts, each participant receives some form of subsidized asset transfer to help jump-start an economic activity. The crucial part of the model is the regular monitoring and coaching of participants by dedicated staff. Ultra poor people generally lack self-confidence and social capital. The skills-training builds up expertise and confidence, but it's usually not enough to boost self-confidence. Weekly household visits by staff allow for monitoring but even more so for "coaching" over the 18 to 24 months of the program. During these meetings staff help participants with business planning and money management, along with social support and health and disease prevention services. In several instances, linking up with a health care service provider-either government clinics or nongovernmental options, has proven critical.

Peer support in group meetings and self-help groups also builds confidence. Several pilots have created "village assistance committees," which typically include local community leaders, such as the clergy, teachers, or village elders. These committees support participants during the program and can continue to help after the program is over. Committees offer participants close support and integrate isolated people into the community without overburdening program staff. 


\section{Figure 4: Growing Ultra Poor out of poverty Trajectory}

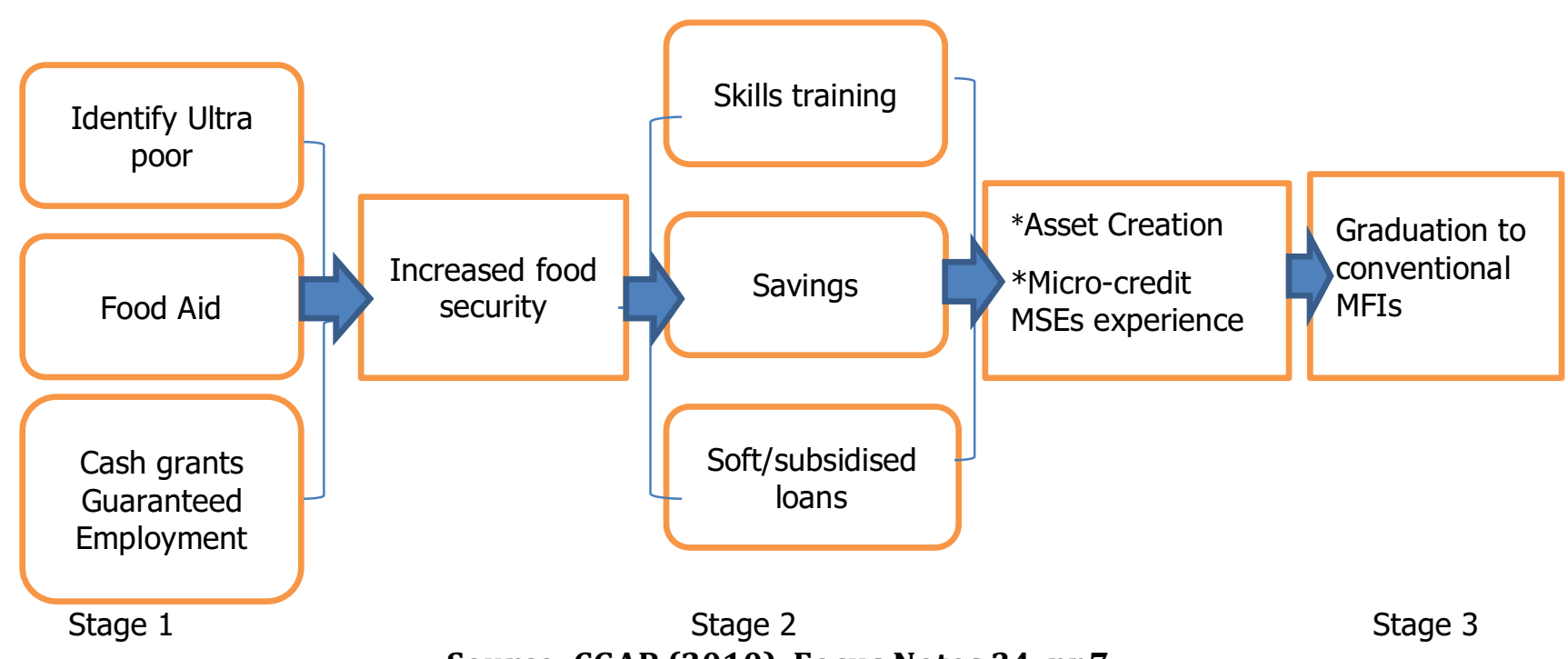

Source: CGAP (2010), Focus Notes 34, pp7

Figure 4 shows a trajectory of the long route of ultra-poor growing out of poverty to become microfinance client. It requires social protection and promotion programs i.e food aid, trainings in income generating activities, program designs, inculcating the habit of savings, soft micro loans, among others culminating into graduating to formal financial access.

\section{IMPLICATIONS FOR POLICY AND INSTITUTIONAL DESIGN}

The patterns revealed by Figure 1 and Figure 2 showed that average loan impacts diminishes with very low income levels hence, attempts to scale up credit-based solutions to rural poverty are likely to surge quality of life and bridge income gaps. Several of the more thoughtful recent contributions to the microcredit literature, in particular Montgomery (1996) and Rutherford (1996) emphasize that a different model of lending to the poorest may be required focused on the provision of savings facilities, simple insurance facilities (against drought) and small consumption loans with flexible repayment periods. Although this model would almost certainly achieve a financial product better matched to the needs of the poorest in most areas, it would not necessarily increase short-term impact, in terms of the productivity of the asset which the loan finances. It may be best to think in terms of a sequence in which the very poor, by borrowing for consumption, are able to reduce gradually their income-vulnerability and thereby get themselves into a position where they can contemplate riskier investments in working capital, the hiring of extra-family labour, and ultimately fixed capital.

Such sequences might permit the poorest to overcome successively the barriers of selfexclusion, social exclusion and institutional exclusion that currently block their access to micro-enterprise loans (Hulme \& Mosley, 1996, chap. 5, Jaabi, 2015). However, such sequences take time to work successfully, and involve a lengthy process of learning from experience and from error. The process is not readily compatible with targetry such as "reaching 100 million of the world's poorest families with micro-credit for self-employment by 2005."

\section{CONCLUSIONS}

The findings above are consistent with the claim that more impact is recorded with high income levels able to afford high interest rate charges for sustainability relative to social protection programmes associated with high subsidy index. It is possible to claim that what we have described as the "impact curve" represents a general tendency with a possibility of a trade-off for high profitability or low impact with poverty reduction objective. Nonetheless, 
there are sufficient materials in the findings to motivate, encourage and warn on the profitability and poverty reduction nexus. The fact that impact curves for financially sustainable institutions lie above those for non-sustainable institutions, may be that the adoption by microfinance institutions of those design features are significantly associated with good financial performance (market interest rates, savings and insurance facilities, intensive collection of loan instalments and incentives to repay) will increase poverty impact as well as financial sustainability. The adoption of the package described had indeed worked well in the reform of some of the institutions, in particular, the Bank Rakyat Indonesia unit Desa schemes (see Patten \& Rosengard, 1998) but it has also failed to work in other cases, such as the Malawi Mudzi Fund's attempt to replicate Grameen Bank principles into a land-scarce, labour-rich area of Africa (Hulme \& Mosley, 1996, chap. 16). Nonetheless, it is encouraging that the impact curve, which in the short term appears as a trade-off between poverty impact and overall loan impact, can in some cases be shifted. As the Bolivian, Indonesian, Bangladeshi and Sri Lankan institutions (Hulme \& Mosley, 1996, 1998) demonstrate, microfinance institutions do learn from their field experience how to operate more effectively. Other design features tried as yet only on an experimental basis, such as flexible repayment patterns on consumption loans and interest rates inversely related to loan size, may also increase the average rate of return on loans to the very poor and thereby move the trade-off upward.

\section{References}

CGAP and Ford Foundation. 2009. Graduation Program handout, May. http://www.cgap.org/gm/documentFoundation Graduatio Program Handout 2009.pdf; www.cgap.org/graduation

Christen, R., Rhyne, E. and Vogel, R. (1994) Maximising the Outreach of Microente@se Finance: The Emerging Lessons of Successful Programs. USAID, Washington DC.

Dreze, J. and Sen, A. K. (1990) Hunger and Public Action. Oxford University Press, Oxford. Hossain, M. (1984) Credit for the rural poor: The experience of the Grameen Bank of Bangladesh. Bangladesh Institute of Development Studies, Dhaka.

Hashemi, Syed, and Richard Rosenberg. 2006.“Graduating the Poorest into Microfinance: Linking Safety Nets and Financial Services.” Focus Note 34. Washington, D.C.: CGAP, February.

Hossain, M. (1988) Credit for Alleviation of Rural Poverty: The Grameen Bank in Bangladesh. IFPRI, Washington DC. Hulme, D. and Mosley, P. (1996) Finance Against Poverty: Effective institutions for Lending to Small Farmers and Microenterprises in Developing Countries, 2 Vols. Routledge, London.

Khandker, S., Khalily, B. and Khan, Z. (1993) Grameen Bank: what do we know? Unpublished paper.

Lipton, M. (1968) The theory of the optimizing peasant. Journal of Development Studies 4, 327-351.

Mahajan, V. and Ramola, B. G. (1996) Financial services for the rural poor and women in India: access and sustainability. Journal of International Development (I,(March-April), 21 l-226.

Matin, I., M. Sulaiman, and M. Rabbani. 2008. "Crafting a Graduation Pathway for the Ultra Poor: Lessons and Evidence from a BRAC Programme.” Manchester, United Kingdom, Chronic Poverty Research Centre, March. www.bracresearch.org

Montgomery, R. (1996) Disciplining or protecting the poor? Avoiding the social costs of peer pressure in microcredit schemes. Journal of International Development 8,(March-April), 289-305

Mosley, P. (1996) Financial sustainability, targeting the poor and credit constraints in farmers' decision making: a poorest, and income impact: are there trade-offs for reinterpretation. Journal of Development Studies 20, microfinance institutions? World Bank Focus Note, 5-21. No. 5 (Dec

Otero, M. and Rhyne, E. (1994) The New World of Microenrerptise Finance. Intermediate Technology Publications, London.

Patten, R. H. and Rosengard, J. (1991) Progress with Profits: The Development of Rural Banking in Indonesia. The International Centre for Economic Growth, San Francisco.

Pitt, M. and Khandker, S. (1996) Household and Intra-household Impact of the Grameen Bank and Similar Targeted Programs in Bangladesh, World Bank Discussion Paper 320. World Bank, Washington DC. 
Remenyi, J. (1991) Where Credit is Due: Income-generating Programmes for the Poor in Developing Countries, Intermediate Technology Publications, London.

Robinson, M. (1996) Some key questions on finance and poverty. Journal of International Development S,(MarchApril), 153-161.

Rogaly, B. (1996) Micro-finance evangelism, "destitute women" and the hard selling of a new anti-poverty formula. Development in Practice 6,(May), 100-112.

Rutherford, S. (1996) Learning from the urban informal sector. Paper presented at an international workshop on Poverty and Finance in Bangladesh. IDPAA and Proshika, Dhaka.

Weeks, J. (1971) Uncertainty, risk and wealth and income distribution in peasant agriculture. Journal of Development Studies 8, 28-36.

Yaron, J. (1991) Successful Rural Finance Institutions. Agricultural Policies Department, World Bank, Washington DC 